\title{
The Effect of Political Competition, Financial Independence, Expenditure and Government Complexity on Internet Financial Report
}

\author{
Nyoman Ayu Wulan Trisna Dewi ${ }^{1, *}$ I Putu Julianto ${ }^{1}$ I Gd Nandra Hary Wiguna ${ }^{1}$
}

\author{
${ }^{1}$ Department of Economic and Accounting, Universitas Pendidikan Ganesha, Singaraja, Indonesia \\ *Corresponding author. Email: ayu.wulan@undiksha.ac.id
}

\begin{abstract}
For this purpose, Law Number 14/2008 came into effect, as well as the Minister of Home Affairs's Instruction Number 188.52/1797/SJ/ 2012. However, up until this point, we have fallen short of our transparency goals. It is the goal of this research to analyze how political competitiveness, financial independence, expenditure, and government complexity impact the disclosure of government financial information in Indonesia. djpk.kemenkeu.go.id and the local governments' official websites provided the secondary data for this study. Multiple linear regression analysis is used to test hypotheses. The findings of this study show that political competitiveness and financial independence have an impact on the disclosure of financial information, whereas expenditures and government complexity have no effect. Political and financial independence have an essential role in supporting the publication of government financial information as a form of transparency in government finance management, according to this study's findings for both legislative and executive branch officials
\end{abstract}

Keywords: Internet Financial Report, Political, Financial, Complexity.

\section{INTRODUCTION}

The issuance of regulations related to e-government as stated in Presidential Instruction No. 3/2003 is the beginning of a more transparent and accountable governance reform. The implementation of egovernment is an effort to increase transparency and accountability that can support the creation of good governance through the provision of open information and public services that can be accessed by the entire community. Disclosure of information that can be accessed by the public can reduce information asymmetry in government financial statements as a trigger for corruption [1].

Law No. 14/2008 was enacted in order to facilitate the establishment of e-government, which includes laws on the disclosure of public information. As a form of accountability and transparency, the government is expected to make public information available to the general public. In addition, the Minister of Home Affairs Instruction No. 188.52/1797/SJ/2012 on Increasing Transparency of Regional Budget Management (TPAD) was issued by the Ministry of Home Affairs. Local governments have been instructed by the Minister of Home Affairs to implement TPAD content menus on their websites. However, since the enactment of regulations related to public information disclosure in 2008 and instructions from the Minister of Home Affairs in 2012, until now, openness of public information has not achieved maximum results. The regulation on public information disclosure has not yet attained the aim, according to the central information commission's performance report for 2019. The results of the achievement of public organization' compliance with the regulation on Public Information Disclosure have still not been able to reach the target, which is only $74.37 \%$ of the $80 \%$ achievement target. In 2016, 2017, and 2018, [2] found that only a few local governments provide all of the financial report components on their official websites, and that many local governments lack an official website. Even though there are legislation requiring local governments to post financial reports on their official websites, these data confirm a phenomenon: a low level of public disclosure.

We need to look at what influences the publication of financial information on local government websites as a result of this phenomena. Various studies have been conducted related to the variables that affect the disclosure of local government financial information. This research is based on the legitimacy theory which 
explains that public organizations in this case government institutions in order to continue to operate, an organization must act within the limits of behavior or norms that are acceptable to the community around its environment. This study builds on previous research [3] which revealed that political competition and financial independence effect information disclosure on local government websites. This study will revisit political competitiveness and financial independence, as well as regional expenditure and government complexity. According to [4], [5], [6] and [3], political competition improves financial reporting reliability. Political competition is a competition that aims to gain power in controlling the government and allocating available resources to meet the interests of the public and political interests [6]. Local governments that have high political competition have greater incentives to report information because of the supervision of their political opponents [7].

In addition to political factors, disclosure of financial information also depends on regional finances. According to [8], [9], and [3], regional wealth that demonstrates financial independence has a beneficial impact on financial disclosure. Local governments can fund their own operations, development, and public services if they are financially independent [16]. Laswad et al. (2005 in [3]) explained that regions with large wealth will increase competition for a public office which has an impact on the current ruling local government will be encouraged to show the public about the fulfillment of their previous political promises during the election through openly presenting information about its good performance to the public. Regarding financial factors, this study will add regional expenditures as a proxy for financial factors that affect the disclosure of financial information. Regional expenditures are expenditures made by local governments to carry out their authorities and responsibilities to the public and government. In addition, the high degree of community service will urge the government to post its financial statistics on the local government website. [8] and [10] found that regional spending influences financial transparency on local government websites.

The intricacy of municipal administration can also put pressure on the government to reveal financial information. The local government's actions will get more difficult as it prioritizes more issues. [6] discovered that local government complexity affects regional financial data availability and accessibility.

Several previous studies have studied disclosure of information within the scope of district/city government, this research expands the object of research, namely provincial governments throughout Indonesia, so that the results obtained can describe or show the overall level of transparency in each region in Indonesia and develop previous research through the addition of new variables, namely regional expenditure and local government complexity. Based on this explanation, this study will analyze the political, financial, and government complexity aspects that influence financial transparency on local government websites. This study's goal is to provide empirical evidence about the factors of financial information disclosure on provincial government websites in Indonesia.

\section{LITERATURE REVIEW}

\subsection{Legitimacy Theory}

Legitimacy theory is an idea that in order to continue to operate, an organization must act within the limits of behavior or norms that are acceptable to the community around its environment [21]. Wherever the existence of an organization, the organization must try to adapt to its environment. Creating harmony in each of its operational activities with the behavior or social norms of the local community can be one way to be accepted by the environment [11].

In explaining government activities, the main source of funding comes from the community. The community entrusts local financial management to the government. This has implications for the role of the government's responsibility to always disclose its performance and accountability for the use of finance in the form of financial reports openly to the public. As a party with lots of information, the government is responsible for the public's trust in continuing to realize openness and accountability [12].

The legitimacy of an entity depends on public expectations regarding the performance of the entity concerned. In maintaining this legitimacy, the most crucial thing is communication with the community. One form of communication that can be carried out by government entities in maintaining and strengthening their legitimacy to the public is by submitting information on their performance on a regular basis [7]. To promote public trust in government, the official local government website can provide useful information about government performance.

\subsection{Financial Information Disclosure}

The Minister of Home Affairs issued Instruction 188.52/1797/SJ/2012 to improve Regional Budget Management Transparency (TPAD). Transparency of regional financial management is the openness of local governments to their regional financial information [13]. Local governments must establish TPAD content menus on their websites. The government must disclose some financial data, such as RKA SKPD; RKA PPKD. 


\subsection{The Effect Of Political Factor On Financial Information Disclosure}

[6] stated that political competition is a competition that aims to gain power in controlling the government and allocating available resources to meet the interests of the community and political interests. Local governments that have high political competition have greater incentives to report information because of the supervision of their political opponents [7]. Public perception of government performance is strongly influenced by issues and media reports that arise. They will also monitor the fulfillment of political promises made during the election [14]. This causes local governments competing in high-level politics to bear higher monitoring costs by providing further information that demonstrates the fulfillment of their promises before the campaign (Laswad, 2005 in [6]).

The theory of legitimacy explains that to be able to operate sustainably, an organization must act within the limits of behavior or norms that are acceptable to the community around its environment [21]. To account for local government performance, entities with considerable political competitiveness will be required to publish regional financial statistics on the official local government website. Studies by [4], [5], [6], and [3] suggest that political competition influences financial reporting transparency. In order to be held accountable for their actions, governments must provide financial information to the public.

Thus, the first hypothesis proposed in this study is as follows

$\mathrm{H}_{1}$ : Political competition has a positive effect on financial information disclosure

\subsection{The Effect of Financial Independence on Financial Information Disclosure}

Comparing the real amount of local own-source revenue to the overall local revenue shows the government's financial capabilities. The larger the local own-source revenue percentage, the greater the regional independence in funding government operations, which indirectly implies prosperity. This is in line with the explanation of [14] that the level of independence shows the ability of the region from local revenue sources to finance regional operational expenditures in realizing regional development and services to the community. This independence of local governments can reflect good government performance so that they tend to disclose more financial information to show stakeholders as a signal of good public management. In accordance with signaling theory (Spence, 1973, in [15]) that the sending party (the owner of the information) gives a signal in the form of information that reflects the condition of an organization that is beneficial to the recipient (the public). High regional independence encourages the government to release financial information to the public. Wider availability of information will reassure interested parties.

Research conducted by [8], [9], and [3] shows that regional wealth that shows regional independence has a positive influence on financial information disclosure. The higher level of regional independence in self-funding activities in the regions can give a signal in the form of good government performance, so that these conditions can encourage the government to disclose financial information openly.

Thus, the second hypothesis proposed in this study is as follows:

$\mathrm{H}_{2}$ :. financial independence has a positive effect on financial information disclosure

\subsection{The Effect of LGS Expenditure on Financial Information Disclosure}

Regional expenditures are made by local governments to fulfill their duties to the community and government [16]. According to the 2004 Regional Spending Law, regional expenditures are intended to protect and improve the community's quality of life through enhancing basic services, education, health, social, and public amenities. It is expected that high regional spending will reflect good quality community services, encouraging the government to post its financial information on the local government website as a form of accountability for public funds spent. According to the stewardship theory, financial disclosure is linked to local governments' (stewards) responsibilities to the public (principals) in the mandate [12], [8], [10]

Thus, the third hypothesis proposed in this study is as follows:

$\mathrm{H}_{3}$ : Local government expenditure has a positive effect on financial information disclosure.

\subsection{The Effect of LGS Complexity on Financial Information Disclosure}

Regions with a high level of government complexity directly indicate that the region has a number of priorities in developing the region. Every affair that becomes a regional priority is carried out by Regional Apparatus Organizations (RAO) in accordance with their respective duties. The division of tasks in government is intended to enable RAO to work effectively. The more government affairs will be proportional to the number of RAO who are implementing these affairs.

Agency theory explains that the principal, in this case the top management, supervises the agent to carry out effective, efficient, and economical tasks in accordance with the principle of value for money [17]. Local 
governments are progressively optimizing their actions, notably in the presentation of financial statements, to raise public knowledge of the government's clean, accountable, and responsible behavior. To alleviate information asymmetry, more RAO must be disclosed [17].

The local government's actions will get more difficult as it prioritizes more issues. According to [12], government complexity increases financial disclosure. Due to the intricacy of municipal governance, financial information may be required. [6] discovered that local government complexity affects regional financial data availability and accessibility (RFI).

Thus, the third hypothesis proposed in this study is as follows:

$\mathrm{H}_{4}$ : Local government complexity has a positive effect on financial information disclosure.

\section{METHOD}

\subsection{Research Method}

This study's research design is quantitative. The quantitative method is a research method based on positivism that examines populations or samples utilizing research tools and quantitative or statistical analysis to test hypotheses [18]. In this study, we will explore the correlation between four variables: political competitiveness, financial independence, expenditure, and government complexity.

\subsection{Population and Sample}

This survey included all 34 Indonesian provincial governments. This study's sample is the province government, which contains complete data, including an accessible official website, a 2020 financial report audited by the BPK, regional demographic data, and results of the Regional Head General Election in each region.

\subsection{Independent and Dependent Variables}

\subsubsection{Financial Information Disclosure}

Financial disclosure is the publication of financial data on local government websites. Each municipal government's official website was evaluated for research data. The score index employed in the research of [19] measures the extent of financial information transparency in Indonesia. Then, as indicated in the Instruction of the Minister of Home Affairs Number 188.52/1797/SJ, this measurement index was created. The following is an index for calculating local government information transparency scores:

+1 if the official website of the local government can be found on the first page of a search on Google by typing the name of the local government.

+1 if it only takes three clicks or less to view financial and non-financial information on local government websites.

+1 if financial and non-financial data can be downloaded in multiple formats.

+1 if there is a SKPD RKA Summary

+1 if there is a Summary of RKP PPKD

+1 if there is a Draft Regional Budget

+1 if there is a Draft Regional Regulation on Revised APBD

+1 if there is a Regional Budget

+1 if there is a Regional Budget Amendment to the Regional Budget

+1 if there is a SKPD DPA Summary

+1 if there is a PPKD DPA Summary

+1 if there is LRA SKPD

+1 if there is LRA PPKD

+1 if there is an audited LKPD

+1 if there is a BPK opinion on LKPD

Table 1. Descriptive Statistics

\begin{tabular}{|l|l|r|r|r|r|}
\hline \multicolumn{7}{|c|}{ Descriptive Statistics } \\
\hline & $\mathrm{N}$ & Minimum & Maximum & Mean & Std. Deviation \\
\hline Transparancy_Score & 34 & 3.00 & 15.00 & 10.1176 & 4.71468 \\
\hline Financial_Independence & 34 & .06 & .67 & .3451 & .14632 \\
\hline LnExpenditure & 34 & 28.22 & 31.58 & 29.5414 & .81762 \\
\hline Political_Competition & 34 & .00 & 1.00 & .6765 & .47486 \\
\hline Government_Complexity & 34 & 29.00 & 59.00 & 42.7647 & 7.39803 \\
\hline Valid N (listwise) & 34 & & & & \\
\hline
\end{tabular}

Source: Processed Data, 2021 


\subsubsection{Political Competition}

Political Competition is a competition between political organizations in obtaining authority or power in managing resources. The measurement of this political competition variable refers to research conducted by [20] which uses a dummy variable with the following calculations: 1 for regional heads who are elected from minority political parties and 0 for regional heads who are elected to have a majority political party.

\subsubsection{Financial Independence}

Regional independence describes the ability of the region to finance its activities generated from local revenue. Measurement of regional independence with a comparative value between local revenue and total income, which refers to the research of [3].

\subsubsection{Expenditure}

Expenditures that made by local governments to carry out their authorities and responsibilities to the community and government. Measurement of regional expenditure using Ln total regional expenditure which refers to the research of [8].

\subsubsection{Government Complexity}

The complexity of local government is the number of issues that are the priority of local governments in developing the region. In this study, the complexity of the government is measured by the number of Regional Apparatus Organizations, which are regional apparatus in the regional government as budget/goods users in carrying out their duties and obligations as regional apparatus, which refers to the research of [12].

\subsection{Data Analysis}

\subsubsection{Descriptive statistics}

Descriptive statistics is a data analysis technique by organizing, summarizing, and presenting data into a more informative form. This descriptive data shows the uniformity of the data used in research.

\subsubsection{The classical assumption tests}

The classical assumption test is used to determine whether the data utilized in the study met the required assumptions. The assumption tests include normality, multicollinearity, and heteroscedasticity.

\subsubsection{Hypothesis Testing}

Hypothesis testing is carried out to see whether the previously formulated hypothesis is in accordance with the results of the research that has been done. The hypothesis test carried out is:

\section{a. Variable Significance Test (t-test)}

The t-test was conducted to see how much each independent variable had an effect on the dependent variable with a significance level of $5 \%$. Significant variables are indicated by $p$-values that are less than the level of significance.

\section{b. Coefficient of Determination Test (R2)}

The coefficient of determination reflects how well the study's independent variables explain the dependent variable's fluctuation. From 0 to 1, R2 indicates the ability to explain fluctuations in the dependent variable. A high $\mathrm{R} 2$ value implies a superior research model since the independent factors better explain the dependent variable.

\section{RESULTS \& DISCUSSION}

\subsection{Statistic Descriptive}

According to Table 1, the greatest score for transparency of local government financial information on the province government's official website is 15.00 , while the minimum score is 3.00 . The value of transparency of local government financial information is quantified using a score system with fifteen indicators, three from accessibility and twelve from financial reports required by Minister of Home Affairs Instruction 188.52/1797/SJ.

The average value of the transparency of local government financial information on the official website of the provincial government is 10.11 or $67.45 \%$ if presented as a percentage. Thus, the value of transparency of local government financial information is classified as quite high because it is already above $50 \%$, but has not yet reached $100 \%$. Based on the author's observations on each of the official provincial government websites, there are still provincial governments that have not made or have made a special menu of budget transparency, but the published financial reports are not complete as stipulated in the Instruction of the Minister of Home Affairs Number 188.52/1797/SJ on each the official website.

The maximum value of political competition is 1.00 ; while the minimum value of political competition is 0.00 . The average value of political competition is 0.6765 . This means that the majority of provincial regional heads who serve in each province come from non-central coalition parties. Twenty-five (25) of the 34 provincial regional heads came from non-central coalition parties, while the rest came from central coalition parties.

The maximum value of the total comparison of PAD and provincial government revenues is 0.67 trillion rupiah, while the minimum value of the total comparison 
of PAD and provincial government revenues is 0.06 . The average value of the total comparison of PAD and provincial government revenues in Indonesia is 0.3451 . This shows that the level of regional independence in Indonesia reaches $34.51 \%$.

The maximum value of provincial regional expenditure is 31.58 , while the minimum value of the total comparison of PAD and provincial government revenue is 28.22. The average value of provincial spending in Indonesia is 29.54 .

The maximum value of the number of provincial apparatus organizations is 59.00, while the minimum value of the number of provincial regional apparatus organizations is 29.00 . The average value of the number of provincial apparatus organizations in Indonesia is 42.76 .

Table 2. Hypothesis Test Result

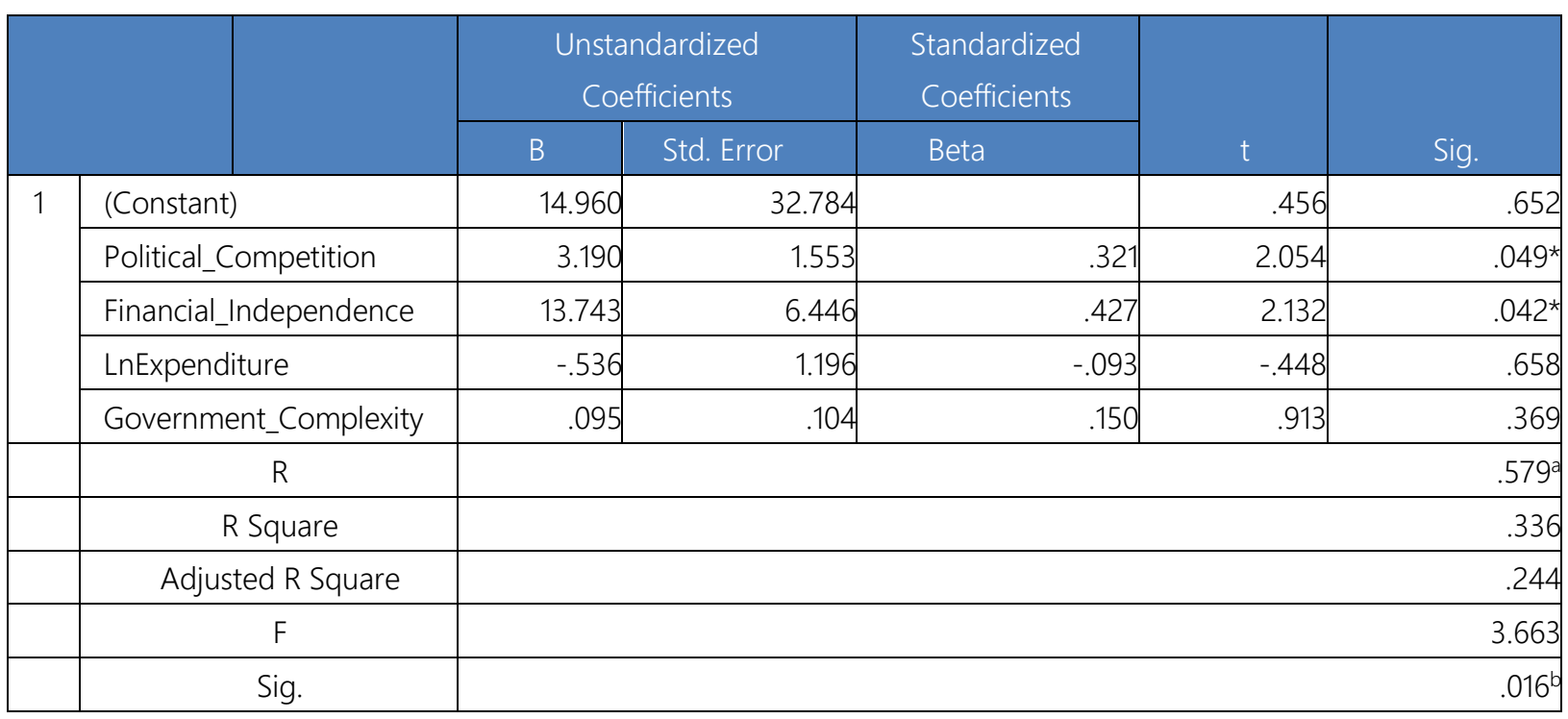

Source: Processed Data, 2021

\subsection{Classic assumption test}

\subsubsection{Normality test}

The normality test of the data was carried out using the Kolmogorov-Smirnov test. If the KolmorogovSmirnov Sig significance number $>0.05$, it indicates that the data is normally distributed, otherwise if the Kolmorogov-Smirnov Sig significance number is $<0.05$, it indicates that the data is not normally distributed. The results of the normality test can be seen in table 2 which shows the Kolmorogov-Smirnov significance number of 0.099 and the Shapiro-Wilk significance number of 0.278 . These results indicate that the data is normally distributed.

\subsubsection{Multicollinearity Test}

There should be no link between the independent variables. The independent variables are not orthogonal if they are connected. A regression model is said to be multicollinear if its VIF is less than 10 and its tolerance number is less than 0.10 . Table 2 demonstrates that all variables in this investigation had a tolerance value of higher than 0.1 and a VIF $<10$. There is no multicollinearity.

\subsubsection{Heteroscedasticity Test}

The Glejser test shows that the research model is free of heteroscedasticity, where the significant value of all independent variables is more than 0.05 .

\subsection{Hypothesis Test}

The independent variables of political competition and regional independence have a substantial effect on financial information disclosure, while regional expenditure variables and government complexity have no significant effect, as shown in Table 2. Based on the results of regression testing, the regression equation formed is:

Financial_Information_Disclosure= 14.960+3.190(Political_Competition)+13.743(Financial _Independence)-0,536(LnExpenditure) +0.095 (Government_Complexity) $+\varepsilon$

\subsubsection{The Effect of Political Competition on the Disclosure of Local Government Financial Information}

Based on Table 2 Regression Test Results, it can be seen that the significance value of the political 
competition variable is smaller than the probability value of 0.05 , which is 0.049 . Thus, it can be concluded that $\mathrm{H} 1$ is supported, which means that political competition has a significant positive effect on the disclosure of financial information of the provincial government.

\subsubsection{The Influence of Financial Independence on the Disclosure of Local Government Financial Information}

Based on table 2 Regression Test Results, it can be seen that the value of sig. the regional independence variable is smaller than the probability value of 0.05 , which is 0.042 . Thus, it can be concluded that $\mathrm{H} 2$ is supported, which means that regional independence has a significant positive effect on the disclosure of financial information of the provincial government.

\subsubsection{The Effect of Expenditures on the Disclosure of Local Government Financial Information}

Based on table 2 Regression Test Results, it can be seen that the value of sig. the regional expenditure variable is greater than the probability value of 0.05 , which is 0.658 . Thus, it can be concluded that $\mathrm{H} 3$ is not supported, which means that regional spending does not have a significant positive effect on the disclosure of financial information of the provincial government.

\subsubsection{The Effect of Government Complexity on the Disclosure of Local Government Financial Information}

Based on table 2 Regression Test Results, it can be seen that the value of sig. the government complexity variable is greater than the probability value of 0.05 , which is 0.369 . Thus, it can be concluded that $\mathrm{H} 4$ is not supported, which means that the complexity of the government does not have a significant positive effect on the disclosure of financial information of the provincial government.

\subsubsection{Coefficient of Determination Test Results}

The coefficient of determination measures how much variation in the dependent variable's value can be explained by the independent variables. Table 2 shows that the Adjusted R square number is 0.244 based on the examination of the coefficient of determination. The variables of political competition, regional independence, regional spending, and government complexity explain just $24.4 \%$ of the variation in the level of local government financial disclosure. The remaining $75,6 \%$ is explained by factors not included in the linear regression model.

\subsection{Discussion}

The results of testing the first hypothesis show that political competition has an effect on the information disclosure of the provincial government website. This shows that the more regional heads elected from noncentral coalition parties, the more transparency of financial information, especially in terms of publishing regional financial information on their respective government websites.

According to [4] local governments will have to work harder to achieve legitimacy in areas with strong political rivalry in order to maintain popular trust. These findings confirm the legitimacy hypothesis, which states that an organization must act within the bounds of acceptable behavior or standards to maintain its validity [21]. In this sense, local governments must provide more information to the public via their official websites, notably financial data as a form of government accountability for local budget management. In order to maintain public trust, elected local governments must keep political pledges made during campaigns [14].

In line with [5], [6] and [20], political competition has a major positive effect on local government openness in Indonesia. The study found that the more political rivalry there is, the more motivated the government is to release local government financial statistics on the official government website.

The results of testing the second hypothesis indicate that financial independence has an effect on information disclosure of the provincial government websites. This shows that the higher the local revenue generated, the more motivated local governments are to disclose their financial information openly through the local government's official website. The high level of independence shows the ability of the region from local revenue sources to finance regional operational expenditures in realizing regional development and services to the community. This reflects the good performance of the government. Good government performance can give positive signals to the public that the government has carried out its duties by prioritizing the principle of value for money and the government has behaved in a clean, accountable and responsible manner so that the government is increasingly encouraged to disclose its performance to the public. This supports the legitimacy theory that wider disclosure of information will provide positive signals to interested parties, including the public which reflects the organization's activities in accordance with its environment. The results of this study strengthen the findings of [8], [9], and [3] which explain that regional wealth that shows regional independence has a positive influence on financial information disclosure. The higher level of regional independence in self-financing activities in the regions can give positive signal about good government 
performance, so that these conditions can encourage the government to disclose financial information openly.

In testing the third hypothesis, it was shown that regional expenditure had no effect on financial disclosure on the official local government website. [22] concluded that regional expenditures have little effect on financial information transparency. These findings show that regional expenditure does not influence financial disclosure. This is probable because many provincial governments still do not fully provide budgetary information on their official local government websites [23]. The survey found that just $67.45 \%$ of financial information is disclosed on official local government websites, on average.

The findings of testing the fourth hypothesis show that the number of Regional Apparatus Organizations has no effect on the disclosure of financial information on the regional government's official website. Based on these findings, local governments are not required to provide financial information due to their complexity. [24] and [25] have found that the number of RAO does not alter the level of disclosure in local government financial statements. The findings contradict the legitimacy paradigm, which claims that the more RAOs there are, the more stewards there are to manage a government and offer information to the principal. This is presumably because there are still many inconsistencies in the creation of financial statements. According to [26], the Supreme Audit Agency (BPK) found that the management and financial administration of RAOs had not yet carried out their functions and duties in accordance with applicable regulations, so local governments are not required to disclose financial information on their official websites.

\section{CONCLUSION}

This study aims to determine the influence of political factors as proxied by political competition, financial factors as proxied by financial independence and regional expenditures, and government complexity as proxied by the number of regional apparatus organizations. This study found that regional expenditure and government complexity have little effect on the publication of local government financial information. This research informs legislators and executive branch officials that political variables and regional financial capacity play a significant role in encouraging the publication of government financial information as a form of financial management transparency.

This research is still far from perfect and still needs to be developed further for the next research. This research only focuses on the scope of local government, further research can develop in the scope of other public institutions such as the central government and ministries. In addition, further research is expected to extend the research time not only within 1 year. As a development, further research can examine audit quality factors in the form of audit opinions and audit findings that have not been tested in this study. A good audit opinion indicates a good quality of financial statements so that it is possible to encourage the disclosure of financial information in a transparent manner.

\section{REFERENCES}

[1] Elbahnasawy, N. G "E-Government, Internet Adoption and Corruption: An Empirical Investigation," World Dev., no. 57, pp. 114-126, 2014.

[2] Lestari and Rahardjo, "Determinan Transparasi Informasi Keuangan Pada Laman Resmi Pemerintah Daerah Provinsi Di Indonesia Tahun 2016-2018," Diponogoro J. Account., vol. 9, no. 3, p. 2, 2020.

[3] H. Pranaswati and K. Kiswanto, "Determinan Transparasi Pelaporan Keuangan Pemerintah Daerah Provinsi Di Indonesia," J. Ilm. Ekon. Bisnis, vol. 25, no. 3, pp. 273-289, 2020.

[4] A. Garcia and J. . Garcia, "Determinants Of Online Reporting Of Accounting Information By Spanish Local Government Authorities," Local Gov. Stud., vol. 36, no. 5, pp. 679-695, 2010.

[5] M. D. Trisnawati and K. Achmad, "Determinan Publikasi Laporan Keuangan Pemerintah Daerah Melalui Internet," J. Ilm. Mhs. FEB, vol. 2, no. 2, 2013.

[6] R. Annisa and H. Murtini, "The Determinant Of Regional Financial Information Transparency On The Official Website of Local Government," Account. Anal. J., vol. 7, no. 1, pp. 43-51, 2018.

[7] W. M . Rahim and D. Martani, "Analisis Pengaruh Tingkat Akses Internet, Kompetisi Politik, Opini Audit, Karakteristik Pemda, Dan Karakteristik Demografi Terhadap Pengungkapan Informasi Keuangan Dan NonKeuangan Website Pemerintah Daerah," Simp. Nas. Akunt. XIX Lampung, pp. 24-27, 2016.

[8] K. A. D. Pratama, D. N. S. Werastuti, and E. Sujana, "Pengaruh Kompleksitas Pemerintah Daerah, Ukuran Pemerintah Daerah, Kekayaan Daerah, Dan Belanja Daerah Terhadap Pelaporan Keuangan Pemerintah Daerah (Studi Pada Pemerintah Kabupaten/Kota di Bali Tahun 20102013)," JIMAT (Jurnal Ilm. Mhs. Akuntansi) Undiksha, vol. 3, no. 1, 2015.

[9] K. Utomo and Y. Aryani, "The Determinat Of 
Financial Information Disclosure On Indonesian LGs Website," Asia Pacific Fraud J., vol. 1, no. 1, pp. 85-102, 2017.

[10] P. Priyastiwi and N. Saputra, "Pengaruh Kinerja Keuangan Dan Karakteristik Daerah Terhadap Penyajian Laporan Keuangan Pemerintah Daerah Melalui Internet," J. Ris. Manaj. Sekol. Tinggi Ilmu Ekon. Widya Wiwaha Progr. Magister Manaj., vol. 6, no. 2, pp. 157-172, 2019.

[11] Y. Hiola and A. D. M. Rusidi, "Pengaruh Kinerja Keuangan Terhadap Kepatuhan Pengungkapan Informasi Keuangan Di Website Dengan Opini Audit Dan Lingkungan Politik Sebagai Pemoderasi (Studi Pada Pemerintah Provinsi, Kota, Dan Kabupaten Di Sulawesi)," Simp. Nas. Akunt., vol. 18, 2015.

[12] P. Hardiningsih, I. Januarti, C. Srimindarti, and R. . Oktaviani, "Does The Characteristics Of Regional Government And Complexity Affect On The Disclosure Regional Financial Statements," J. Akunt. Dan Audit. Indones., vol. 23, no. 2, pp. 106-116, 2019.

[13] N. Setyaningrum, “Analisis Transparansi Pengelolaan Keuangan Daerah Berbasis Website Pada Pemerintah Daerah Di Bali, NTB, Dan NTT," Account. Bus. Inf. Syst. J., vol. 6, no. 4, 2017.

[14] I. Wau and R. Ratmono, "Analisis Faktor-Faktor Yang Mempengaruhi Ketersediaan Dan Keteraksesan Internet Financial Reporting Oleh Pemerintah Daerah," Diponogoro J. Account., vol. 4, no. 4, pp. 187-198, 2010.

[15] R. Hahn and D. Reimsbach, "Bringing Signaling Theory To Intermediated Voluntary Disclosure. Comentary On 'Detecting False Accounts In Intermediated Voluntary Disclosure' by Patrick Callery And Jessica Perkins," Acad. Manag. Discov., vol. 7, no. 1, pp. 155-157, 2021.

[16] A. Halim, Akuntansi Sektor Publik Akuntansi Keuangan Daerah. Jakarta: Penerbit Salemba Empat, 2012.

[17] C. Maulana and B. Handayani, "Pengaruh Karakteristik, Kompleksitas Pemerintah Dan Temuan Audit Terhadap Tingkat Pengungkapan Wajib LKPD," Account. Anal. J., vol. 4, no. 4, 2015 .

[18] Sugiyono, Metode Penelitian Kuantitatif, Kualitatif, dan R\&D. Bandung: Alfabeta, 2017.

[19] D. Ratmono, "Pelaporan Keuangan Pemerintah
Daerah Di Internet: Pengujuan Teori Intitusional dan Keagenan," Media Ilm. Akunt., vol. 1, no. 2, pp. 28-48, 2013.

[20] I. M. Adiputra, S. Utama, and H. Rossieta, "Transparency Of Local Government In Indonesia," Asian J. Account. Res., vol. 3, no. 1, pp. 123-138, 2018.

[21] G. O’Donovan, “Environmental Disclosures In The Annual Report: Extending The Applicability And Predictive Power Of Legitimacy Theory," Accounting, Audit. Account. J., 2002.

[22] R. Puspita and D. Martani, “Analisis Pengaruh Kinerja Dan Karakteristik Pemda Terhadap Tingkat Pengungkapan dan Kualitas Informasi Dalam Website Pemda," Univ. Indones., 2012.

[23] A. T. Nainggolan and D. Purwanti, "Analisis Faktor-Faktor Yang Mempengaruhi Transparansi Informasi Keuangan Daerah Via Website," Simp. Nas. Akunt. XIX Lampung, 2016.

[24] D. Setyaningrum and F. Syafitri, "Analisis Pengaruh Karakteristik Pemerintah Daerah Terhadap Tingkat Pengungkapan Laporan Keuangan,” J. Akunt. dan Keuang. Indones., vol. 9, no. 2, pp. 154-170, 2012.

[25] N. Khasanah and S. Rahardjo, "Pengaruh Karakteristik, Kompleksitas, dan Temuan Audit Terhadap Tingkat Pengungkapan Laporan Keuangan Pemerintah Daerah," Diponogoro J. Account., vol. 3, no. 2, pp. 864-874, 2014.

[26] R. Widanti, "Analisis Faktor Yang Mempengaruhi Tingkat Pengungkapan Wajib Laporan Keuangan Pemerintah Daerah Di Indonesia," Univ. Islam Indones., 2019. 